\title{
Cash holding: static trade-off theory or financing hierarchy theory
}

\author{
Siyi Yu*, Xuemeng Guo \\ Beijing Jiaotong University, Beijing, China \\ a.17120673@bjtu.edu.cn, b. xmguo@bjtu.edu.cn \\ ${ }^{*}$ Corresponding author
}

\begin{abstract}
Keywords: static trade-off theory, financing hierarchy theory, cash holding
\end{abstract}
\begin{abstract}
The theory to explain cash holding has always been the subject of scholars' research. The static trade-off theory of cash holdings and the financing hierarchy theory explain the cash holdings of enterprises from different perspectives, and have also been proved in different companies. This article mainly analyzes the cash holdings of companies based on the public financial data and discusses whether the static trade-off theory or the financing hierarchy theory have the best explanation of cash holding in Chinese listed firms. After that, we study the factors that affect corporate cash holdings. The empirical results show that China's companies not only meet the static trade-off theory but also meet the financing hierarchy theory, and the financing hierarchy theory has better explanatory power in the excess cash-holding companies.
\end{abstract}

\section{Introduction}

In a perfect capital market, cash holdings have nothing to do with the value of the company, because companies can get the cash needed in the capital market without paying any transaction costs. However, the capital market is not perfect. Enterprises need to consider various aspects to determine the best cash holdings. Why does the company hold cash and how much cash should companies hold? There has been great controversy in the academic community regarding the behavior of companies holding cash. The early scholars mainly explain the company's cash holding behavior from three theories: trade-off theory, financing hierarchy theory and agency theory [1]. The trade-off theory holds that the company has an optimal level of cash holding, which is the result of balancing the marginal benefits of cash holdings with marginal costs. However, the financing hierarchy theory believes that the company does not have an optimal level of cash holdings. Corporate cash holdings are often used as a buffer between retained earnings and investment demand. The agency theory focuses on the agency conflict between management and shareholders, and believes that in companies with poor governance mechanisms, the private interests of management will make them tend to use free cash flow to make excessive investments and hold more cash ( Jensen, 1986). Previous studies have confirmed that cash holding behavior is consistent with the static trade-off theory (Opler et al., 1999; Kim et al., 1998) [2]. The level of cash holdings is positively related to the company's growth opportunities, business risks, capital expenditures, and the difficulty of entering the capital market. It is negatively related to company size, capital structure, and dividend payments. The conclusions of Wei Zhou and Shilei Xie's (2007) research support the static trade-off theory; Taoying Peng and Wei Zhou (2006) believe that the static trade-off theory is more suitable for explaining the cash holding behavior of Chinese listed companies than agency theory. Only a few studies support the the financing hierarchy theory. For example, Kalcheva and Lins (2003) found that cash holding is positively related to the company's long-term opportunities, scale, and its cash flow, and it also negatively related to debt level and capital expenditure. Jianwei Cheng and Weixian Zhou (2007) found that the financing hierarchy theory has stronger explanatory power than the static trade-off theory. Regarding the agent theory of cash holding behavior, scholars at home and abroad do not have very consistent conclusions. Dittmar et al. (2003), Ferreira and Vilela (2004), and Gimey et al. (2003) found that companies with better investor protection and capital markets which is perfect hold less cash. However, Mikkelson and Partch (2003) and Bates et al. (2009) did not find the agent problem based on cash holding. Domestic scholars Renyi Zhang and Chunjiang Liu (2005), Guoliu Hu et al (2006), Dongzhi Yu et 
al (2006), Yuhe Xin and Liping Xu (2006) also attempted to examine the influence of corporate governance mechanisms on cash holding behavior from the perspective of agency theory[3]. However, no unanimous conclusion has been reached. The disagreement between the empirical evidence of the company's cash holding theory has gradually widened, which also provides an opportunity for the study of this article.

Domestic and foreign scholars mainly compare the theory of cash holding behavior and the financing hierarchy theory from a static perspective, making the difference between the two is not as clear as people might think. The static trade-off theory and the financing hierarchy theory have yielded similar empirical evidence about the factors affecting the company's cash holding level (Gogineni et al., 2012; Ferrera and Vilda, 2004; Opler et al., 1999; Jianwei Cheng and Weixian Zhou , 2007). At the same time, because the theory of agency and the financing hierarchy theory are both to examine information asymmetry, therefore, drawing on the ideas of Frank and Goyal (2003), this paper also classifies agency theory into the financing hierarchy theory and believes that information asymmetry and agency problems are two reasons for generating a financing order. Based on the above two reasons, this article borrows from Opler et al. (1999)'s idea of investigating company's cash holding behavior. On the one hand, the static trade-off theory and the financing hierarchy theory are introduced into the research category of cash holding behavior to test that listed companies in China are more in line with the theory of static trade-offs or the financing hierarchy theory; on the other hand, the company establishes a linear regression model of the company's cash holding level on its influencing factors, and examines the influence of the company's cash holding behavior from a static perspective. The main significance of the article is to further study the theory of conformity of cash holdings of listed companies in China and provide a better explanation for the company's cash holding behavior.

\section{Literature Review}

The theoretical literature on cash holding mainly includes static trade-off theory based on economic theory, financing hierarchy theory and agency theory based on behavior theory [4].The static trade-off theory of cash holdings holds that companies holding enough cash can help companies get better investment opportunities, but holding too much will bring opportunity costs and management costs to the company. Therefore, the trade-off theory believes that companies should balance the cost of holding cash with equity to determine the optimal level of cash holdings.

The financing hierarchy theory comes from the theory of the order of capital structure (Myers, 1984; Myers, Majluf, 1984). The financing hierarchy theory thinks that in order to reduce the financing costs brought about by information asymmetry, the company will first use its own cash, then choose the safe and less risky debt, and ultimately choose external equity financing. Therefore, when the company has more investment opportunities and faces external financing constraints, it will hold as much cash as possible. Compared with the trade-off theory, the financing hierarchy theory holds that there is no target cash holding in the enterprise, and it merely regards cash as a regulator between retained earnings and investment demand.

Agency theory mainly stems from the contractual nature of modern enterprises. The separation of management rights and ownership leads to the agency problem between managers and shareholders. Managers who are under free disposal rights usually don't meet shareholders' requirement because of their own interests such as on-the-job consumption, creation of corporate empire, and job protection. The agency problem also includes agency issues between corporate creditors and shareholders or between large and small shareholders. The agency theory believes that excessively high cash holdings will bring more free discretion to management. There should be as little cash holding as possible to resolve the issue of agency costs. Different cash holding theories have different perspectives on the interpretation of the company's cash holding level. The level of cash holding of an enterprise is an important issue to be determined. A listed company considers the cost and benefits of cash holdings to determine the optimal cash holding or just holds cash by the order of internal financing, debt financing, and equity financing. The cash holding of a company is a question that needs to be explored. Based on the above research, this paper will use all the 
available data of Chinese listed companies to study the static balance of cash holding theory and the adaptability of financing order theory to determine that which theory is more in line with cash holdings.

\section{Research Hypothesis}

This article is mainly based on the data of Chinese companies and explores whether the static trade-off theory or the financing hierarchy can better explain the company's cash holding level. Theoretical explanations for the company's cash holdings mainly include static trade-off theory and financing hierarchy theory. Both theories explain the utility of cash holdings in corporations and have been proven in different companies. This put forward the main assumptions of the article [6].

Ha: Static trade-off theory can explain the cash holdings of Chinese companies

Hb1: Pecking Order Theory Can Explain Cash Holdings in Chinese Companies

Hb2: Does the Pecking Theory have better explanations for companies holding excess cash?

\section{Empirical Research}

In order to study whether the static trade-off theory or the financing order theory that can better explain the cash holding status of Chinese listed companies, this paper conducts empirical tests on the data of all Chinese listed companies from 2000 to 2016 through the Guotai'an database. This article excludes financial companies, utilities, including electrical, water, heat, transportation, and communications industries. The article main variables explained as shown in the [Table1].

\subsection{Variable Selection}

The meaning of variable used in this article are as followed.

Table 1. Specific Description of Variables

\begin{tabular}{cc}
\hline Variable Name & Definition \\
\hline Mean target & An average of the prior three years of cash/net assets \\
\hline Size\&sigma target & $\begin{array}{c}\text { The predicted value from a regression of cash/net assets on real } \\
\text { size and industry sigma }\end{array}$ \\
\hline Sophist target & The predicted value from the Fama-MacBeth regression \\
\hline Peck_x_above_tar_Mean & The flows of funds deficits if the firm is above its mean target \\
level of cash
\end{tabular}

First, a time series analysis of cash holdings was conducted to check whether the company had a target cash level. Dependent variable is the difference between the $t+1$ period of cash/net assets and the $t$ period of cash/net assets, the independent variable is the difference between the actual cash/net assets of the current t period and the target adjustment. The equation is shown in (1). The target cash estimate is in three different ways. The average target adjustment method uses the average of cash/net assets over the past three years. Scale and sigma target adjustments are calculated as actual size and industry sigma cash/net asset regression forecasts. The third measure is to use Fama regression predictions. The applicability test of the financing hierarchy theory is mainly measured 
by the cash flow deficit. The specific regression formula is shown in (2). Cash flow deficits are defined as cash dividends plus capital expenditures, changes in net working capital (minus cash) and maturity of long-term debts minus operating cash Traffic, all variables are adjusted based on total assets less cash, making the data comparable. This article further introduces the product of excess cash and cash deficits, and examines the enterprise's explanation effectiveness of cash holdings by the theory of financing order in the context of holding excess cash. Equation (3) is used for further testing.

$$
\begin{gathered}
\Delta \text { cash } / \text { net } \text { assets }_{t+1}=\alpha_{1}+\beta_{1}\left(\text { cash } / \text { net assets }_{t}-{\text { target cash })+\varepsilon_{1}}^{\Delta \text { cash }_{\text {net }} \text { assets }_{t+1}=\alpha_{2}+\beta_{2} \text { Pecking order }+\varepsilon_{2}}\right.
\end{gathered}
$$

$\Delta$ cash $/$ net assets $_{t+1}=\alpha_{3}+\beta_{3}\left(\right.$ cash $/$ net assets arget $_{t}$ - tash $)+\gamma_{3}$ Pecking order

$$
+\delta_{3} P e c k \_x \_a b o v e \_X+\varepsilon_{3}
$$

\begin{tabular}{|c|c|c|c|c|c|c|c|c|c|c|}
\hline & 1) & 2) & 3) & 4) & 5) & 6) & 7) & 8) & 9) & 10) \\
\hline \multirow[t]{2}{*}{ Mean target } & -0.096 & & & & -0.096 & & & -0.096 & & \\
\hline & $(-0.97)$ & & & & $(-0.97)$ & & & $(-0.97)$ & & \\
\hline \multirow[t]{2}{*}{$\begin{array}{c}\text { Size\&sigma } \\
\text { target }\end{array}$} & & $\begin{array}{l}-0.619 * \\
* *\end{array}$ & & & & $\begin{array}{l}-0.619 * \\
* *\end{array}$ & & & $\begin{array}{l}-0.620 * \\
* *\end{array}$ & \\
\hline & & $(-4.96)$ & & & & $(-4.96)$ & & & $(-4.99)$ & \\
\hline \multirow[t]{2}{*}{ Sophist target } & & & $0.007 *$ & & & & $0.007 *$ & & & $0.007 *$ \\
\hline & & & $(-1.86)$ & & & & $(-1.86)$ & & & $(-1.86)$ \\
\hline \multirow[t]{2}{*}{ Pecking order } & & & & $\begin{array}{l}0.003^{* *} \\
*\end{array}$ & 0.003 & $\begin{array}{l}0.009 * * \\
*\end{array}$ & $0.003^{* *}$ & 0.002 & -0.001 & $0.006^{* *}$ \\
\hline & & & & $(-2.59)$ & $(-0.7)$ & $(-2.77)$ & $(-2.57)$ & $(-0.54)$ & $(-1.00)$ & $(-2.57)$ \\
\hline \multirow[t]{2}{*}{$\begin{array}{c}\text { Peck_X_abov } \\
\text { e_tar_Mean }\end{array}$} & & & & & & & & 0.001 & & \\
\hline & & & & & & & & $(-0.17)$ & & \\
\hline \multirow[t]{2}{*}{$\begin{array}{c}\text { Peck_x_abov } \\
\text { e_tar_Size }\end{array}$} & & & & & & & & & $\begin{array}{l}0.029 * \\
* *\end{array}$ & \\
\hline & & & & & & & & & $(-3.15)$ & \\
\hline \multirow[t]{2}{*}{$\begin{array}{c}\text { Peck_x_abov } \\
\text { e_tar_Soph }\end{array}$} & & & & & & & & & & $-0.004 *$ \\
\hline & & & & & & & & & & $(-1.94)$ \\
\hline $\mathrm{N}$ & 11053 & 18169 & 18169 & 18169 & 11053 & 18169 & 18169 & 11053 & 18169 & 18169 \\
\hline r2_a & 0.009 & 0.383 & 0 & 0 & 0.009 & 0.383 & 0 & 0.009 & 0.383 & 0 \\
\hline
\end{tabular}

\subsection{Regression coefficient text}

Table 2. Adaptive Regression Coefficient

Note: $* \mathrm{p}<0.1 * * \mathrm{p}<0.05 * * * \mathrm{p}<0.01$

From the regression results, in the regression of 1) to 3), a simple OLS regression was used to examine whether the company had the best cash holding under different target cash calculation methods. In addition to the coefficient t-test under regression using the first method is not significant, the t-test of the regression coefficients of the other two methods are significant, and the empirical results assume that Ha is correct. The regression of 4) mainly tests the applicability of Chinese listed companies to the financing hierarchy theory. The results show that the cash holdings of Chinese companies can be explained by the financing hierarchy theory, assuming that $\mathrm{Hb} 1$ is verified. The three regressions in columns 5) to 7) allow the change in cash to be affected both by the target adjustment model and the order-financing model. In all three regressions, it can be seen that both the static trade-off theory and the financing hierarchy theory can explain the cash holdings of listed companies. The last three regressions in [Table2] (8) to 10)) show the effect of the financing hierarchy theory on corporate cash holdings in the presence of excess cash. It can be seen from this that the financing hierarchy theory can have a good explanation for the cash holdings of companies that have excess cash. Assume that Hb2 is confirmed. 


\subsection{Extensibility test}

After learning that the static trade-off theory and the financing hierarchy theory can well explain the cash holdings of Chinese listed companies, the factors that affect the cash holdings of enterprises are further studied. Using LnCash as the dependent variable, tobin'Q, size, cflow, NetWC, and indsigma are multiple variables for independent regression. The regression was first performed using the Fama-MacBeth method. This method was used to estimate cross-sectional regressions once a year. This method eliminates the problem of cross-sectional regression residual sequence correlation in time series. The Fama-MacBeth model effectively treats each year as a separate cross-section. This paper finds that the size of the cash flow and net working capital will have a significant impact on the company's cash holdings. These coefficients are not only statistically significant, but also generally economically significant. Through Fama-MacBeth regression analysis, the market-to-book ratio, and cash flow are consistent with static trade-off theory and the financing hierarchy theory. However, compared with the financing hierarchy theory, the scale is more consistent with the static trade-off theory. It is unclear whether the financing hierarchy theory foreshadows the working capital and industry fluctuations. Next, four additional regression estimates are provided in the [Table3].This article uses time series cross-sectional regression of the year and cross-sectional regression of the time series adjusted for the industry. The two regression results are the same as the Fama-MacBeth regression results, but the t-statistic is higher. Second, we use the average of the sample period variables of the company used in the estimation of the target adjustment model in [Table2] to perform regression estimation. The regression coefficient estimate is consistent with other regression estimates. Finally, the paper uses fixed-effect regression. Except for two variables, this regression is the same as the cross-sectional regression result of the time series.

Table3. Extensibility Coefficient

\begin{tabular}{|c|c|c|c|c|c|}
\hline & 1) & 2) & 3) & 4) & 5) \\
\hline & Fama-MacBeth & Year & Year\&industry & Cross-Section & $\mathrm{FE}$ \\
\hline \multirow[t]{2}{*}{ cons } & $-1.750 * * *$ & & & $-1.294 * * *$ & $-1.621 * * *$ \\
\hline & $(-7.24)$ & & & $(-6.67)$ & $(-16.47)$ \\
\hline \multirow[t]{2}{*}{ tobin } & $0.072 * * *$ & $0.037 * * *$ & $0.029 * * *$ & $0.046^{* * *}$ & $0.013^{* * *}$ \\
\hline & $(-4.46)$ & $(-13.75)$ & $(-10.93)$ & $(-6.91)$ & $(-5.45)$ \\
\hline \multirow[t]{2}{*}{ size } & $-0.037 * *$ & $-0.067 * * *$ & $-0.019 * * *$ & $-0.058 * * *$ & $-0.022 * * *$ \\
\hline & $(-2.47)$ & $(-11.26)$ & $(-3.05)$ & $(-3.90)$ & $(-2.81)$ \\
\hline \multirow[t]{2}{*}{ cflow } & $1.739 * * *$ & $0.504 * * *$ & $0.498 * * *$ & $2.305 * * *$ & $0.234 * * *$ \\
\hline & $(-8.5)$ & $(-16.82)$ & $(-17.26)$ & $(-13.42)$ & $(-9.89)$ \\
\hline \multirow[t]{2}{*}{ NetWC } & $0.325 * * *$ & $0.216^{* * *}$ & $0.082 * * *$ & $0.532 * * *$ & $-0.325 * * *$ \\
\hline & $(-3.6)$ & $(*-9.08)$ & $(-3.33)$ & $(-9.21)$ & $(-11.87)$ \\
\hline \multirow[t]{2}{*}{ indsigma } & $1.087 * * *$ & $-0.000 * *$ & 0 & $-0.000 *$ & $0.000 *$ \\
\hline & $(-3.27)$ & $(-2.05)$ & $(-1.08)$ & $(-1.82)$ & $(-1.66)$ \\
\hline $\mathrm{N}$ & 21187 & 21187 & 21187 & 21187 & 21187 \\
\hline r2_a & & 0.795 & 0.812 & 0.151 & -0.115 \\
\hline r2_w & & & & 0.005 & 0.018 \\
\hline
\end{tabular}

\section{Conclusions}

Cash is the lifeblood of business survival and development [5]. After choosing cash holding as the research topic, this paper first carried out the research and review of related theories. From the theoretical review, we found that different theories have different views on the interpretation of cash holdings, which leads to the research themes of this article and the applicability of the theory to listed companies in China; secondly, using the public data of Chinese listed companies from 2000 to 2016, through an empirical study to study the effect of static trade-off theory and financing hierarchy theory on the cash holdings of Chinese companies. It is found that both the static trade-off 
theory and the financing hierarchy theory have a good explanatory power for the cash holdings of listed companies in China, and the finance hierarchy theory can better explain the company's over-cash holding; Finally, based on the existing data, a further empirical study was conducted on the influencing factors of corporate cash holdings. It was found that the company's tobin' $Q$ and cflow are directly proportional to the company's cash holding, and the size of the company is inversely proportional to the company's cash holding. From the results of empirical research we have reached the following conclusions:

The level of cash holdings of Chinese companies meets the static trade-off theory and also meets the financing hierarchy theory.

In companies with excess cash, the situation of cash holding is more in line with the financing hierarchy theory.

When making decisions on the level of cash holdings, enterprises will not only consider the costs and benefits of holding cash, but also consider the financing difficulties caused by the asymmetric information of external financing, and give priority to internal financing.

\section{References}

[1] Xi Bing, Study on factors influencing cash value of Chinese listed companies, Jinan University, 2011.

[2] X. Q. Yang, Jie Sun, Corporate cash holdings: literature review and enlightenment, Modern Finance and Economics, vol.9, pp.26-34, 2006.

[3] J. W. Cheng, W. X. Zhou, Cash holdings of listed companies: balance theory or pecking theory, China's Industrial Economy, vol. 86, pp. 1-10, 2007.

[4] Z. Y. He, Factors influencing cash holding level of China's publish-listed companies, Research Publishing Science, vol. 81, pp. 312-323, 2017.

[5] Q. W. Zhang, Corporate cash holdings: a theoretical and empirical study, Liaoning University, 2017.

[6] Tim Opler, LeePinkowitz, Rene Stulz, Rohan Williamson, The determinants and implications of corporate cash holdings, Journal of Financial Economics, vol. 27, pp.127-146, 1999. 